\title{
Values and Ethics Education as a Panacea to Conflict and Crises in Nigerian Urban Communities
}

\author{
Dr. Adekola, G. \\ Department of Adult \& Non-Formal Education \\ University of Port Harcourt \\ Port Harcourt, Nigeria \\ E-mail: Adekolag@Yahoo.Com
}

Received: February 10, 2012

Accepted: April 15, 2012 Published: May 1, 2012

doi:10.5296/jse.v2i2.1374

URL: http://dx.doi.org/10.5296/jse.v2i2.1374

\begin{abstract}
Conflict and crises have become an endemic problem in Nigeria. Government has always adopted the military option of Joint Task Force (JTF) to quell the crises. However, the failure and limitations of the JTF option as response to conflict and crises management in Nigerian calls attention to desirability of a change in strategy to achieve permanent and sustainable peace in Nigerian urban communities. This desirability for change in approach is based on the fact that sustainable peace correlates with development. In the old African society, values and ethics education were the major instrument for evolving a peaceful society. Through this medium, the traditional African society was able to evolve a system of co-existence in which everyone has concern for the welfare of every other person and was able to establish a conflict and crisis free society. It is based on this strength of traditional education that emphasised ethics and values to achieve a peaceful society that this paper discusses values and ethics education as a panacea to constant conflict and crises in Nigerian urban communities.
\end{abstract}

Keywords: Values, Ethics, Education, Panacea, Conflicts, Nigeria

\section{Introduction}

Scholars in the fields of social sciences and humanities are concerned with the concept and nature of community. Broadly, they have classified communities into two types i.e, urban community and rural community. Accordingly to Oyebamiji and Adekola (2008) both urban and rural communities co-exist in all countries of the world because no country is entirely rural or urban. Thompson in Oyebamiji and Adekola (2008) revealed that in East Africa, urban populations are about $9 \%$, about $30 \%$ in Ghana and $21 \%$ in Nigeria. Despite the 
relatively low population of the urban population, peaceful co-existence is always threatened because there is constant conflict and crises among the people.

The term 'urban' according to Otite (2002) is human congregation in a relatively large area. Urban communities in Nigeria therefore are a relatively large, densely populated settlement of heterogeneous people. Being densely populated and heterogeneous, Oyebamiji and Adekola (2008) observed that the urban people are generally anonymous and this gives them opportunity to freely enjoy freedom on almost every aspects of life without concern for what happens to other people.

This lack of concern for what happened to other people has always resulted into selfishness and intolerance among the people. Conflicts and crises exist at the individual and group levels have become a common occurrence in urban communities in Nigeria. Lopez (2011) observed that Nigerian urban communities is a place where many (especially the youths) have learnt to behave without a sense of responsibility and accountability except to ourselves and interests. These behaviours are further complimented by the messages the adults and the elite consciously or unconsciously send the youths by what they admonish them to do and how they do the admonishment. The situation of conflict and crises prone behavior in Nigerian urban communities has degenerated to a situation that is enough to alarm and depress many.

Suffice here to mention some conflicts and crises whose scars cannot easily be erased from the minds of Nigerians. The conflicts and crises, for easy understanding can be classified into religious, political, economic, boundary and communal crises. Examples of religious crises in Nigerian urban communities include the Maitasine crises in Maidugiri in 1982, the Kano riot of 1953, 1999 etc, the Boko Haram crises in Bauchi, Gombe and Maiduguri in 2010 and 2011, the Boko Haram attack on The Nigeria Police Headquarters and The United Nations Building in Abuja (Nigeria Federal Capital) in 2011 and the Jos crises in 2009-2011. Examples of political crises in Nigerian urban communities include the "Wet E" (spray with petrol) crisis in Ibadan in 1964, post election crises in Ibadan, Ondo, Akure, and Osogbo in 1983, the June 12 crises in all urban centers in the Southwestern Nigeria in 1995, the pre-election crises in Uyo in 2011, post election crises in Northwestern Nigeria in 2011, the struggle for power among National Union of Rural Transport Workers in Ibadan and Lagos in 2011. The list is endless.

Examples of the economic crises in Nigeria urban communities include the the various attack and vandalisation of oil installations and companies in Port Harcourt, Warri, Bayelsa and other parts of the Niger Delta by the various ethnic militias in the Niger Delta Region, the October 1, 2010 bombing of the venue of the celebration of national independence in Abuja by the Movement for the Emancipation of the Niger Delta (MEND), the various strikes by the labour Unions that often times turn violence and the oil subsidy removal crisis in January 2010. Examples of the community crises include the Ijaw/Itsekiri war in 1994, the Odua Peoples Congress (OPC) versus Hausa community crises in Mile 12 Lagos, Obaship tussle in Ondo etc. 
Despite the constant occurrence and re-occurrence of conflicts and crises in Nigerian urban communities, government in response has always adopted the military approach as solution to the problem. Government style has always been the introduction of Joint Task Force (JTF) to quell the crises. As at 2011, Joint Task Forces are presently operating under different military tags in more than half of the 36 state capitals in Nigeria. However, it needs to be pointed out that, this approach has not been able to record full success anywhere, not sustainable and waste human and material resources.

The recorded failure or limitations of the JTF approach as response to conflict and crises in Nigerian urban communities call attention to desirability of a change in strategy to achieve a permanent and sustainable peace in Nigerian urban communities. This desirability for change in approach is based on the fact that sustainable peace correlates with development.

According to Fafunwa (2004), every society whether simple or complex has its own system of training and educating its youths towards good life. In the old Africa, education plays significant role as tool for induction of the youths into the society and preparation for adulthood. Education in the old Africa emphasized social responsibility and moral values. It was an integrated experience that combines others forms of training with character building. As observed by Osaat (1999) traditional education projected character training and present religious beliefs. Education then was an aggregate of all the activities by which a child or young adult develops the ability, attitudes and other forms of behavior which are of positive values to the society he lives. Through this medium, the traditional African society was able to evolve a system of co-existence in which everyone has concern for the welfare of every other person and was able to establish a conflict and crisis free society. It is based on this strength of traditional education that emphasised ethics and values to achieve a peaceful society that this paper discusses values and ethics education as a panacea to constant conflict and crises in Nigerian urban communities.

\section{Conflict}

The term conflict, according to Ugwu (2001), is coined from a Chinese word Conflictus which means to strike together. Though the concept of conflict in peace literature has gone beyond the physical content usage to include moral connotations Ugwu (2008:24) defines conflict as a social situation in which incompatible goals and activities occur between two parties who hold antagonistic feelings towards each other and attempt to control each other. Writing in the same line, Folger (2002:5) described conflict as the interaction of interdependent people who perceived incompatible goals and interference from each other in achieving those goals.

From the moral angle Imhabekhai (2009:103) observed that conflict connotes disagreement, imbalance or distortion in beliefs and values and situations within, between or among individuals, persons, groups, communities, states, tribes or countries. To him conflict results from changes in perception and subsequent reaction to such changes depending on which side of the divide individuals or groups belong. Similarly Mereni (1991) opined that it is the perception of existence of the incompatible preferences, the desire to achieve these preferences and the behavior expanded in the direction of gaining and protecting such 
preferences that essentially characterizes a state of conflict. According to White and Bedner (1986) in Imhabekhai (2009), conflict is the interaction of inter-dependent people or groups who perceives incompatible goals and interference from each other in achieving these goals.

Every human society strives to achieve peace, though peace according to Nzeneri and Adekola (2006) is not the absence of war or armed conflict since according to Ekong (1988) conflict is not only exhibited by overt physical violence but may also assume the form of sabotage of programmes and undermining of morale. Conflict is an inevitable aspect of human interaction. However, Imhabekhai (2009) noted that when conflicts are poorly managed, they degenerate into crises. Crises according to Zwei consult (1997) is a situation of intense danger. It is a climax and turning point in a continuous antagonism, hostility, clashes, protests, demonstrations and violence. Crisis denotes trouble, disruption, and eclipse into disruption and break of law and orders. It is a climax of conflict.

Conflicts are of different types. It can be interpersonal or intra-personal. It could be inter-group or intra-group. It can also be national or international. At whatever level, the causes of conflict according to Imhabekhai (2009) includes poor or absence of communication, religious intolerance, competition over resources, inability of leaders to meet members needs, neglect by government, generational gap, behavior of companies to host communities and inadequate distribution of resources. Conflict may also result from political intolerance, unhealthy rivalry, ignorance, ideological extremism, boundary adjustment and international diplomacy. Consequences of conflict may include loss of life and properties, disunity, dissipating development, use of resources on conflict/crises management, suspicion that could lead to further crises, low development etc.

\section{Ethics}

According to Omoregbe (1993) ethics has no univocal definition becouse It has been defined in various ways by scholars from various field of practice and background. However, Omoregbe (1993) described ethics as the branch of philosophy which deals with the morality of human action. It can also be described as the branch of philosophy which studies the norms of human behavior. Ethics is the normative science of human conducts.

In most situation Akinepelu (2002) claimed that ethics is used synonymously with morals or morality He observed that there is always a close but complex inter-relationship between ethics and morality such that the use of the word ethics or ethical quickly injure up in our minds the word 'morality'. According to Njang (1998) in Bamisaiye (2001), ethics seeks to explain the notion of right and wrong, good and bad and of behavior which is moral and immoral. Hence Omoregbe (1993:5) noted that "morality is the basis of ethics". Ethics however, deals with talks, discussions, analysis and judgment on morals and morality. it is concerned with discourse on moral concepts such as good, bad, right and wrong. Ethics is a word that is commonly used to describe principles of belief and actions, code of conducts, set of principles, rules and regulations that undergird and direct human actions and against which such actions are evaluated. 
In line with the views of Akinpelu (2002), ethics in this discourse, means behaviours or attitudes that are considered moral. Before an action or attitude is considered ethical or moral, it must conform to the code of conduct in the society and satisfy the expectations of the generality of the people.

Values like morals and ethics are the rules by which we make decisions about right and wrong, should and shouldn't, good or bad. Osaat (2011) described values as things considered worthwhile, desirable, right or good and thus craved for and applied on daily basis to enhance co-existence by people. Values also tell us which behavior is more important and acceptable in a particular situation and time. Thus, Osaat (2011) noted that value is not content oriented but habit oriented. Values are therefore the guiding principles for accepted behaviors in the society. It is the extent to which a behaviour conforms with the value system of the people that determines the acceptability or rejection of such behavior. Various issues on which decisions are made depend on the value attached to them. Thus acceptability of values according to Osaat (2011) has to do with the internal consistency of a person's behavior or attitude or the relevance of things and issues to the individual or the society.

Values are of different types, the common and highly guarded values in African societies include respect for elders, hard work, co-operation, sincerity, good moral, cultural protection, care or love for others, etc. These values are what the traditional system of education train individuals to imbibe and exhibit in behavior and interaction with other people in the society. With values as the determinant of behavior and guideline for interaction, the indigenous African society was able to conquer the problem of conflict that could emanate from interactions and competition for resources among the people in the society. However, with the emergence of western education and civilization, the Indigenous value system began to collapse; disrespect for elders replaces respect for elders, laziness and indolence replaced value of hard work, insincerity replaces sincerity, individualism, nepotism and ethnicity replaced values of love and care for others, westernization replaces value of cultural protection. Thus, behavior become polluted, interaction become sore and conflict of different types become the order at the day especially in the urban communities. Omoregbe (1993:214) re-echoing Rousseau's philosophy noted that:

Men were happier and morally better when they were in the state of nature but with the beginning of learning and civilization, studies have replaced virtues, learned men have released virtuous men and academic ability has replaced morality.

Omoregbe (1993) concluded that "since learned men began to appear among us good men have disappeared”.

There is no doubting the fact that it is the disappearance of good men, brought about by replacement of African values with western civilization, that multiply the occurrence of different forms of conflicts that government, international and national organizations and philanthropic individuals are now investing large amount of men and material resources to manage without recording much success. Conflict has because endemic in the Nigerian society with consequences of war, loss of life and properties, hunger, diseases, dislocation and citizens becoming refugees in their own country. 
With the difficulties and near zero success being recorded in conflict management in Nigeria and Nigerian especially youths in urban communities continuously adopting attitude of conflict and crises, it becomes pertinent that government, organizations and community leaders need to change tactics in managing and addressing the problem of conflict in Nigerian urban communities.

\section{Values and Ethics as Panacea to Conflicts and Crises in Nigeria}

The only instrument the indigenous African society adopted to ensure peace in the society was the value system. People were guided by the ethics of behavior and unethical behaviours received due punishment from the leaders and the society at large. The African civilization then developed a set of techniques which enables the society to identify socio-political and axiological problems such as conflict and crisis, and seek appropriate solution through values and ethics. Osaat (2011) noted that a good system of moral education is the best agent to such ethical dynamism without which a society could slack back in the scheme of things. Fafunwa (2004) observed that through this medium, the traditional African society was able to evolve a system of co-existence in which everyone has concern for the welfare of every other person and was able to establish a conflict and crisis free society. If values and ethics can achieve such success in those days, it can still repeat the same in the contemporary society, if integrated into the modern system of education.

The Nigerian National Policy on Education (2004) envisaged this need for integration of values and ethics into the education system when it focuses two out of the seven goals of primary education on moral. The National Policy on Education States goals as:

i) Give citizenship education as basis for effective participation in the contribution to life of the society.

ii) Mould the character and develop sound attitudes and morals in the children.

According to Bamisaiye (2009) one of the seven goals of tertiary education in Nigeria is to "develop and inculcate proper values for the survival of individual and society".

The above aspects of the goals of the Nigerian National Policy on Education revealed that the Policy recognizes the need for morally upright persons in the society. However, it is assumed that the more learned a person is the higher should be his moral standard. This is because education is believed to be a powerful instrument not only for intellectual growth but also for values, moral and ethical principles. In reality, this is not so because evidences abound to show that many highly learnered men display very low standard of morality. This confirms the position of Bamisaiye (2009:6) that "the process of education is an attempt which may succeed or fail. Just as it is possible to succeed in schooling and fail in life, it is also possible to fail in schooling and succeed in life". May be, this is why we have high moral decadence and conflict in Nigerian urban communities where majority of the literate people reside and a relatively moral and peaceful society in the rural communities dominated by illiterates.

According to Bamisaiye (2009) education is a tool for personality transformation. It is not what we have but what we become. The value and ethics dimension of education is the basis 
of this discourse. Values and ethics education become a pertinent issue when we consider the fact that, before a person can be pronounced educated, such a person must have attained some degree of expected behaviour.

If value and ethics education become so important to the social system in Nigeria, the pertinent question then is, where and how can we instill this type of education on Nigerian youths. These questions would lead us to identifying three main elements in values and ethics education. These are the institution, the method of dissemination and instrument of dissemination.

Values and ethics education fall within the scope of both formal and non-formal education. In formal education, value and ethics education can be integrated into the activities and curriculum of subjects in the formal school system. Though every school subjects could accommodate value and ethics; subjects like social studies, history, geography, citizenship education and biology would accommodate and disseminate more of values and ethics education, in the Nigerian context, at the primary and secondary school levels. At the tertiary level, topics or elements of value and ethics education can be inserted into the themes of General Studies Courses to improve the moral status of young graduates who constitute the bulk of Nigerian youths.

The non-formal education is the abode of values and ethics education. Here, values and ethics education often come as an informal learning. The institutions here include: the home; where the parents and senior family members are the instructors, the community; where the community leaders, head of Community Based Organisations (CBOs), change agents and other government officials are the instructors, the media; where the programme presenters and resource persons are the facilitators, age grade and CBOs where the peers and change agents pass instructions and correctional institutions such as the prison and children welfare centre where the officials are the instructors.

The methods of instruction in values and ethics education are inexhaustive. However, the methods include observation, group discussion, role play, apprenticeship etc.

Observation: This is the most frequently used method of teaching and learning in the indigenous African society. In this method, the young person observes the adults how they do, handle and react to matters and events. Even today, Osaat (2011) noted that the values held by the youths are reflection of the value orientation prevalent in the society in which they grew up. Observation could be direct or indirect; in both cases the young persons learn some basic elements of life from the adult or a more senior person in the society.

Group Discussion: Here, children and young adults come under one umbrella to discuss issues in an informal setting. Group discussion can also be used in a formal setting by elders and community leaders to deliberately pass specific educative instructions and messages. A good example is the town hall meeting that is often used by Non-Governmental Organisations to pass specific message to the grassroot people especially in the rural communities. 
Role play: This is a situation in which the children and youth attempt to model or copy the attitudes or behaviours of morally upright adults in the society.

Apprenticeship and Vocational Education: These are methods of acquisition of specific professional skills. In teaching and learning the skills or vocations, instructions on moral values and ethics of the vocation and of life in general are passed by the instructor and assimilated by the learner.

The essence of all these methods is to bring up a complete man; morally upright and accepted by the society. In all the processes, the young person sees the good and ugly sides of life and adopts him/herself to what the society accepts or tends to accept. As observed by Bamisaiye (2009) positive disposition is not just picked up by chance, so is a negative disposition. Lessons on the two are passed and acquired through a learning process over time.

In the non-formal setting, the instruments of teaching values and ethics education include (but not limited to) taboos and superstitions, history and stories, proverbs, religious injunctions and initiation rites. Using the methods of observation, role play, group discussion and apprenticeship; lessons on morality, values and ethics are inserted and deduced from stories, proverbs, religious injunctions etc. all with the aim of building a morally upright man who possesses societal expected values of trust, public interest, tolerance, courtesy, honesty, fidelity, truthfulness, respect, hardwork, dedication, devotion, love, forgiveness, cooperation, rationality, peace etc and can work and live a meaningful life for the progress of self and the society at large.

\section{Conclusion}

The broad objective of development plan in Nigeria today, is to become one of the twenty developed economies of the world by the year 2020. This development objective is tagged vision 20: 2020. To achieve this target, the Nigeria nation desired now than ever a conflict-free nation, attractive to investors and where investment would yield desired results. In recent time, many investors and foreign companies have relocated from Nigeria to neighbouring West African Countries. Specifically, majority of the foreign companies operating in Port Harcourt, Kano and Jos have either relocated to other parts of Nigeria or to Ghana. One of the reasons for such relocation is conflict and unsustainable peace.

To evolve a conflict and crisis free society, this discourse presented values and ethics education as the way out. This paper concludes that values and ethics education, if integrated into the Nigerian education system, posseses the capability to reshape the value orientation of the Nigerian youths and young adults in the urban centres from laziness to hardwork, disrespect to respect for elders and constituted authorities, selfishness to love and care for others and adopt alternative morally ways of demanding for their rights.

Since value and ethics education was successful in the Traditional African Society, this writer believes that there is the need to reawaken non-formal institutions of values and ethics education to stand to their responsibility of inculcating moral values and ethics into the children, youths and young adults so that the problem of immoral behaviours that promote conflict and crises in Nigerian societies could be tackled from the basics of the society. 


\section{References}

Akinpelu, J.A. (2002). Philosophy and adult education. Ibadan: stirling-horden publishers Ltd.

Bamisaiye, O.A. (2001). Some Ethical Issues in Adult \& Non-Formal Education. In J.T. Oxedara; C.N. Anyanwu and M.A.L. Omole. Philosophical foundations of adult \& non-formal education. Ibadan: Ibadan university press.

Bamisaiye, O.A. (2009). What is man, that we should educate him? Ibadan: Ibadan university press.

Ekong, E.E. (2003). An introduction to rural sociology. Uyo: dove educational publishers.

Fafunwa, B. (1974). History of education in Nigeria. London: George Allen and Unwin.

Federal Government of Nigeria. (2004). National policy on education. Lagos: federal government press

Folger, J.P. (2002). Working through conflict: strategies for relationship, Groups and Organizations ( $4^{\text {th }}$ Edition) New York: Longman Printing Press.

Imhabekhai, C.I. (2009). Management of community development programmes and projects. Benin: UNIBEN press.

Lopez, M.A. (2011). Endangered ethics and values. Lagos: Business Day Newpaper- $18^{\text {th }}$ July, 2011.

Mereni, J.I. (1991). Adult education and community development: integration or conflict. In Adult Education and Rural Transformation. Enugu: Asomog printing and publishing Press.

Nzeneri, I.S., \& Adekola, G. (2006). The role of adult and non-formal education in the emergence and maintenance of sustainable peace in the niger delta region of Nigeria. Adult Education in Nigeria, 11, 1-11.

Omoregbe, J. (1998). Ethics: a systematic and historical study. Lagos: Joja educational publishers limited.

Osaat, S.D. (1999). The relevance of moral education to social and political development in Nigeria. Journal of peacher Education and Teaching, 3(1\&2).

Ossat, S.D. (2011). Education in Africa. Port Harcourt: university of Port Harcourt Press.

Otite, R. E. (2002). Partnering in community development: a study of three rural communities in Delta State, Nigeria. university of Ibadan, unpublished Ph.D. Thesis.

Oyebamiji, M. A., \& Adekola, G. (2008). Fundamentals of community development in Nigeria. Port Harcourt: university of Port Harcourt press. 
Ugwu, A.N. (2008). Conflict management for sustainable community development in selected local government areas in Rivers state. university of Port Harcourt, unpublished Ph.D Thesis.

Ugwu, A.N., \& Ijah, C.N. (2011). Women and conflict management for sustainable community development in nigeria. In G. Adekola and M.A Oyebamiji, Topics in Community Development. Port Harcourt: University of Port Harcourt press.

Zwei Consult. (1997). Strategic issues in crisis management. course '97 for NPDL staff Benin City Held at JES motel Sapele road 15-19 september. 